\title{
Strategi Bertahan Bisnis Kue Kering Di Masa Pandemi Covid-19 Melalui Pendekatan Komunikasi Pemasaran Terpadu
}

\author{
Vizcardine Audinovic \\ Universitas Airlangga \\ vizcardine.audinovic-2020@fisip.unair.ac.id
}

\begin{abstract}
Abstrak. Pandemi covid yang belum kunjung usai ini berdampak pada perekenomian Indonesia. Daya beli masyarakat mulai turun, sehingga membuat banyak usaha terutama Usaha Mikro Kecil dan Menengah (UMKM) yang pendapatannya merosot tajam. Termasuk bisnis kue kering Be U Patisserie dan Dapur Muslimah dijalani oleh ibu rumah tangga ini mengalami penurunan di awal pandemi. Kemudian keduanya menerapkan strategi komunikasi pemasaran untuk terpadu untuk dapat bangkit. Tujuan dari penelitian ini untuk mendeskripsikan strategi bertahan bisnis kue kering Be U Patisserie dan Dapur Muslimah selama masa pandemi covid-19 melalui pendekatan pemasaran terpadu. Penelitian ini menggunakan pendekatan kualitatif deskriptif, analisis data menggunakan triangulasi waktu. Teknik pengumpulan data melalui wawancara mendalam dan observasi di media sosial. Hasil penelitian ini menjelaskan bahwa Be U Patisserie dan Dapur Muslimah mampu mempertahankan bisnis kue keringnya di masa pandemi bahkan mendulang kenaikan penjualan karena menerapkan elemen komunikasi pemasaran terpadu. Be U Patisserie menggunakan direct marketing, online marketing, sales promotion dan advertising untuk pemasaran. Hasilnya, usaha ini mengalami peningkatan omzet sebanyak dua kali lipat dan memiliki seorang karyawan. Sedangkan Dapur Muslimah menggunakan direct marketing, online marketing, dan sales promotion. Dapur Muslimah juga mengalami peningkatan omzet dan menambah dua karyawan. Ke depannya Be U Patisserie dan Dapur Muslimah harus mengoptimalkan fitur di media sosial seperti lebih disiplin menunggah konten untuk menambah engagement yang pada akhirnya dapat meningkatkan brand awareness dan penjualan.
\end{abstract}

Keywords: strategi, kue kering, komunikasi pemasaran terpadu, covid-19, UMKM.

\section{Pendahuluan}

Wabah covid-19 yang melanda dunia tak bisa dipungkiri memberi dampak yang luar biasa pada kehidupan masyarakat khususnya di sector ekonomi. Wabah yang berasal dari Tiongkok sejak akhir 2019 ini kemudian perlahan menyebar ke seluruh dunia pada tahun 2020 hingga sekarang. Adanya covid membuat ruang gerak manusia terbatas. Tidak bisa bepergian, harus menjaga jarak, dan tidak bisa beraktivitas leluasa seperti hari-hari biasa demi mencegah penularan penyakit.

Dampak covid yang dirasakan berbagai belahan dunia salah satunya membuat hampir 24 juta masyarakat di Asia Timur dan Pasifik yang memiliki usaha harus gulung tikar. Bank Dunia memprediksi sekitar 35 juta orang tidak beranjak dari kemiskinan, bahkan meningkat mencapai 922 juta di seluruh dunia (Yamali \& Putri, 2020). Ditambah dengan jumlah PHK dimana-mana karena tidak mampu menanggung beban produksi dan operasional. Berdasarkan data Kementerian Tenaga Kerja di bulan April 2020, diketahui sejumlah 114.340 perusahaan sudah melakukan PHK dan merumahkan 1.943.916 tenaga kerja, dengan persentase $77 \%$ sektor formal dan 23\% dari sektor informal (Yamali \& Putri, 2020).

Terlebih pandemi ini belum diketahui kapan berakhir. Meski sudah ada vaksin bukan berarti jumlah pasien berkurang. Justru jumlah penderitanya tiap hari makin meningkat. Jumlah masyarakat yang terpapar virus ini per 21 Juni 2021 mencapai 2.018.113 orang (Sania Mashabi, 2021). Artinya dampak buruk perekonomian juga tidak akan berakhir begitu saja, justru bisa semakin panjang. Akibatnya, banyak aspek lain yang 
terkena imbasnya, seperti usaha restoran, usaha pariwisata, pekerja lepas, serta usaha yang melibatkan banyak orang. Pada sisi penawaran, perusahaan akan mengurangi tenaga kerja dan juga bahan baku. Di sisi lain, permintaan, minat, dan kepercayaan konsumen pada suatu produk menurun. Dampak ini tentu saja mempengaruhi daya beli masyarakat. Perputaran uang akan menurun di mana masyarakat akan lebih berhemat (Hardilawati, 2020).

Apalagi yang dialami Usaha Mikro, Kecil dan Menengah (UMKM) di Indonesia, hantaman wabah covid sangat terasa di bidang ini. Sekitar 1.785 koperasi dan 163.713 pelaku usaha mikro kecil menengah terdampak pandemi. Sebagian besar koperasi yang terkena dampak adalah yang menawarkan kebutuhan sehari-hari. Sementara itu, di sektor UMKM yang paling besar dampaknya pada usaha makanan dan minuman (Thaha, 2020). Selama ini UMKM punya peran yang sangat strategis dalam perekonomian Indonesia. UMKM menyerap tenaga kerja baru dan mampu menggerakkan perekenomian. UMKM juga berhasil membuktikan mampu bertahan dalam kondisi ekonomi yang sulit karena sebagian besar belum terhubung langsung dengan sektor keuangan domestik atau global. Maka dari itu di tahun 1998, UMKM dapat bertahan di krisis keuangan global (Bahtiar \& Saragih, 2020).

Tapi kenyataannya, UMKM harus ikut merasakan dampak pandemi, seperti usaha yang dijalankan oleh dua ibu rumah tangga, Be U Patisserie dan Dapur Muslimah. Sekarang ini bukan hal tabu lagi jika istri ikut berkontribusi dalam perekenomian keluarga melalui bisnis online. Selain untuk menambah pemasukan, para ibu menjadikan bisnis untuk menyalurkan hobi, mengisi waktu apalagi bisa dikerjakan di rumah sambil mengasuh anak (Vernia, 2017). Kini, kedua usaha rumahan tersebut harus memutar otak sejak pandemi melanda. Mereka merasakan dampak covid-19 pada usaha kue keringnya. Sejak adanya pandemi, omzet mereka turun drastis karena sepinya pembeli. Terlebih saat Idul Fitri 2020, di mana biasanya pada moment tersebut mereka mendapat banyak pesanan, tapi harus pupus begitu saja karena adanya Pembatasan Sosial Berskala Besar (PSBB) yang membuat masyarakat harus beraktivitas di rumah, tidak boleh mudik. Akhirnya suasana lebaran yang biasanya penuh suka cita, identik dengan kumpul-kumpul silaturahmi, serta aneka kue berubah menjadi lebih sepi.

Akibat konsumsi masyarakat yang belum pulih pada bulan Ramadan tahun 2020, penjualan pada bisnis kuliner belum bisa bangkit. Oleh sebab itu, pemasukan mereka jauh merosot. Seperti data yang ditemukan Lokadata, konsumsi kue kering di Indonesia cukup tinggi. Konsumsi tertinggi ada di wilayah Sulawesi dengan total 11 juta per tahun dan di Pulau Jawa dengan konsumsi 9 juta per tahun. Pandemi covid-19 inilah yang pertama kali membuat usaha kue kering di berbagai wilayah menjadi jatuh. Tak sedikit usaha yang harus memangkas biaya operasional agar bisa bertahan (Aulia Putri, 2020).

Meski sempat terpuruk, ketika memasuki era new normal secara perlahan Be U Patisserie dan Dapur Muslimah bangkit kembali dan mengalami peningkatan penjualan hingga sekarang. Keduanya dapat bertahan dengan menerapkan strategi komunikasi pemasaran terpadu. Be U Patisserie dan Dapur Muslimah dipilih peneliti sebagai objek penelitian karena keduanya masuk dalam kategori UMKM yang menjual kue kering. Kue kering sebenarnya bukan bahan-bahan pokok yang diperlukan masyarakat selama pandemi. Kue kering biasanya disajikan dalam moment-moment istimewa atau sebagai camilan pelengkap sehingga peluang untuk dikonsumsi masyarakat juga tidak besar, mengingat kondisi perekonomian sekarang yang masih lemah. Tapi sebaliknya, sekarang usaha kue kering ini berhasil meningkatkan penjualannya. Hal ini yang membuat penelitian ini menjadi menarik karena akan mencari tahu seperti apa strategi komunikasi 
pemasaran terpadu yang diterapkan oleh Be U Patisserie dan Dapur Muslimah sehingga dapat bertahan di masa pandemi covid-19.

Dari paparan di atas maka rumusan masalah dalam penelitian ini adalah bagaimana strategi yang digunakan oleh Be U Patisserie dan Dapur Muslimah untuk mempertahankan usaha kue kering di masa pandemi melalui pendekatan komunikasi pemasaran terpadu? Penelitian ini bertujuan untuk mendeskripsikan strategi apa saja yang digunakan oleh Be U Patisserie dan Dapur Muslimah melalui pendekatan komunikasi pemasaran terpadu hingga dapat beradaptasi dengan kondisi bisnis di masa pandemi. Manfaat penelitian ini secara teoritis untuk berkontribusi bagi perkembangan ilmu komunikasi khususnya pada komunikasi pemasaran. Sementara secara praktis dapat memberi rekomendasi bagi para ibu rumah tangga atau masyarakat pelaku usaha lainnya dalam mengimplementasikan komunikasi pemasaran terpadu di masa pandemi covid-19.

Penelitian mengenai komunikasi pemasaran terpadu sudah pernah dilakukan sebelum masuk masa pandemi. Beberapa penelitian sebelumnya seperti yang dilakukan oleh Kusumasari dan Afrilia (2020) tentang strategi komunikasi pemasaran terpadu J\&C Cookies Bandung dalam meningkatkan penjualan. Penelitian tersebut menjelaskan mengenai strategi komunikasi pemasaran terpadu yang dilakukan melalui periklanan, penjualan personal, promosi penjualan, penjualan langsung, acara \& sponsor, dan public relations. Kedua, penelitian dari Purwaningsih dan Purworini (2017) tentang peran IMC dalam pemilihan Mommilk Manahan Solo sebagai pilihan kunjungan konsumen. Penelitian ini mendeskripsikan penggunaan komunikasi pemasaran terpadu melalui advertising, public relations, dan direct sale and promotion dalam menarik minat konsumen Mommilk Manahan Solo dalam menentukan pilihan kunjungan.

Dari dua penelitian tersebut maka penelitian ini dapat dijadikan perbandingan tentang strategi komunikasi pemasaran terpadu pada UMKM bidang kuliner, khususnya kue kering. Perbedaan dengan penelitian sebelumnya terdapat pada objek, yaitu Be U Patisserie dan Dapur Muslimah yang belum pernah diteliti. Selain itu, situasi pandemi covid-19 menjadi suatu pembaruan di penelitian ini.

\section{Metode}

Penelitian ini menggunakan pendekatan kualitatif yaitu penelitian yang menghasilkan data deskriptif berupa kata-kata tertulis atau lisan dari objek dan perilaku yang diamati (Rukajat, 2018). Jenis penelitian yang digunakan adalah deskriptif karena peneliti ingin mendeskripsikan berdasarkan fakta-fakta yang ditemukan di lapangan. Teknik pengumpulan data yang digunakan adalah wawancara mendalam dan observasi. Karena pandemi, wawancara dilakukan secara daring melalui telepon dan chat via Whatsapp. Informan dalam penelitian ini adalah Fatma Nihayati, pemilik Be U Patisserie dan Ima Senia Anwar, pemilik Dapur Muslimah yang dilakukan pada bulan Juni 2021. Observasi dilakukan dengan cara mengamati media sosial Be U Patisserie dan Dapur Muslimah serta status Whatsapp Fatma Nihayati dan Ima Senia Anwar.

Setelah data dan fakta terkumpul, dilakukan analisis melalui tiga tahap, yaitu kondensasi data untuk menyeleksi dan mentransformasi data; penyajian data dalam bentuk uraian yang sudah dikategorisasikan; dan yang terakhir penarikan kesimpulan (Miles \& Huberman, 2014). Langkah selanjutnya adalah menguji keabsahan data. Teknik keabsahan data menggunakan triangulasi waktu, yaitu melakukan pengecekan dengan wawancara, observasi atau teknik lain di waktu dan situasi yang berbeda. 


\section{Hasil dan pembahasan}

Pemasaran komunikasi pemasaran terpadu adalah sebuah rencana dan strategi komunikasi pemasaran yang diadopsi oleh perusahaan besar dan kecil serta menjadi popular diantara firma pemasaran produk dan jasa. American Association of Advertising Agencies (AAAA) mendefinisikan komunikasi pemasaran terpadu sebagai sebuah konsep perencanaan komunikasi pemasaran yang memberi nilai tambah dari rencana yang komprehensif, seperti rencana mengevaluasi peran strategis dari berbagai disiplin komunikasi. Misalnya periklanan, tanggapan langsung, promosi penjualan dan hubungan masyarakat, serta menggabungkan disiplin ini untuk memberikan kejelasan, konsistensi, dan dampak maksimal melalui integrasi saluran pesan (Belch \& Belch, 2018).

Komunikasi pemasaran terpadu memiliki enam elemen yang saling terintegrasi antara satu dengan lainnya. Elemen tersebut antara lain advertising, sales promotion, public relations, personal selling, online marketing, marketing public relation, dan direct marketing. Tiap elemen mempunyai peran masing-masing yang berfungsi saling mengisi untuk mendapat hasil maksimal, yaitu penyampaian pesan yang jelas, konsisten serta memiliki pengaruh kuat pada perusahaan dan produk yang dihasilkan. Sebenarnya, masing-masing komponen dapat berjalan sendiri, tapi akan menjadi lebih dahsyat efeknya jika semua elemen dipadukan. Perusahaan akan mendapat berbagai variasi bentuk kegiatan komunikasi pemasaran (Isnaini, 2004). Yang pertama, advertising adalah seluruh bentuk komunikasi nonpersonal tentang informasi perusahaan, produk, jasa, atau ide melalui media massa dan sifatnya berbayar. Iklan merupakan media yang paling sering digunakan dalam pemasaran karena jangkauannya yang luas. Media massa yang digunakan untuk beriklan adalah televisi, radio, media cetak dan media online (Belch \& Belch, 2018).

Kedua, direct marketing, adalah cara perusahaan atau organisasi untuk berkomunikasi langsung dengan target atau calon konsumen. Tujuan dari direct marketing ini untuk mendapat tanggapan atau membukukan transaksi penjualan. Contoh dari direct marketing adalah mengirim email, menjual secara langsung, memberi sampel.

Ketiga, public relations, adalah upaya mengontrol dan mengelola citra perusahaan. Menurut Frank Jefkins, public relations yaitu kegiatan menciptakan pemahaman melalui pengetahuan untuk menimbulkan dampak positif (Morissan, 2010).

Keempat, personal selling, adalah, bentuk komunikasi langsung antara penjual dengan calon konsumen. Bentuk komunikasi bisa melalui interaksi tatap muka atau melalui telepon. Interaksi ini memberi peluang penjual pada pembeli untuk menjelaskan secara detail mengenai produknya pada calon pembeli. Selain itu juga bisa mendapat feedback secara langsung dari calon pembeli.

Kelima, online marketing, adalah upaya pemasaran melalui internet untuk mewujudkan komunikasi dua arah. Kemajuan internet dimanfaatkan oleh perusahaan untuk memasarkan produk, jasa melalui media sosial, website, blog atau vlog. Kelebihan dari online marketing ini antara penjual dan pembeli bisa saling berinteraksi serta pembelian secara langsung (Belch \& Belch, 2018). Contohnya adalah memberi kupon online, mengadakan giveaway. Keenam, sales promotion adalah kegiatan memberi nilai tambah pada distributor, tenaga penjualan atau konsumen untuk meningkatkan penjualan. Contoh dari sales promotion adalah pemberian diskon (Morissan, 2010).

Penelitian ini membahas bagaimana komunikasi pemasaran terpadu yang diterapkan oleh Be U Patisserie dan Dapur Muslimah di masa pandemi covid-19. Peneliti mendapatkan data kualitatif yang kemudian diolah sesuai metodologi penelitian yang diuraikan secara deskriptif. Be U Patisserie dan Dapur Muslimah adalah usaha kue kering yang dijalankan oleh seorang ibu rumah tangga. Karena terbilang masih baru, keduanya 
melakukan usaha ini sendirian dari proses produksi hingga pemasaran tanpa adanya pegawai.

\section{Potensi dan Tantangan Be U Patisserie dan Dapur Muslimah di Masa Pandemi}

Be U Patisserie merupakan sebuah nama produk kue kering yang dijalankan oleh Fatma Nihayati (32 tahun), seorang ibu dua anak di tempat tinggalnya Kota Sidoarjo. Usaha rumahan ini sudah ada sejak tahun 2019. Namun Fatma baru benar-benar fokus mengembangkan Be U Patisserie pada tahun 2020. Kue kering yang ditawarkan antara lain nastar, kastengel, lidah kucing, choco cereal cookies, sagu keju, choco stick, choco thum print, strawberry thumbprint, red velvet choco stick. Harganya dibanderol mulai dari 60.000 sampai 100.000 rupiah per 400 gram. Kuliner yang ditawarkan kemudian berkembang tidak hanya menjual kue kering, melainkan merambah ke kudapan seperti schotel, klappertart, zuppa soup dan aneka chiffon. Meski terhitung pemain baru, Be U Patisserie memiliki Pelanggan yang tidak hanya berasal dari wilayah Sidoarjo, tetapi sudah tersebar di Pulau Jawa. Target pasarnya adalah kelas menengah ke atas karena bahan baku yang digunakan adalah bahan-bahan berkualitas premium.

Lain halnya dengan Ima Senia Anwar (31 tahun), seorang ibu satu anak yang sudah menjalankan Dapur Muslimah sejak tahun 2017 di Kota Malang. Awalnya Ima yang memang sudah hobi membuat kue ini melihat peluang di kantor suaminya dan lingkungan sekitar yang suka dengan kue buatannya. Dapur Muslimah menawarkan putri salju, kastengel, nastar, lidah kucing, sagu keju, palm cheese sugar cookies, gluten free cookies, dan giant soft cookies. Harga yang dibanderol per 400 gram mulai dari 60.000-95.000 rupiah. Selain kue kering, Dapur Muslimah juga menerima pesanan roti dan cake tergantung pesanan. Pelanggan Dapur Muslimah masih terbatas di area Malang dan sekitarnya. Berikut adalah persamaan dan perbedan dari Be U Patisserie dan Dapur Muslimah sesuai dengan karakteristiknya.

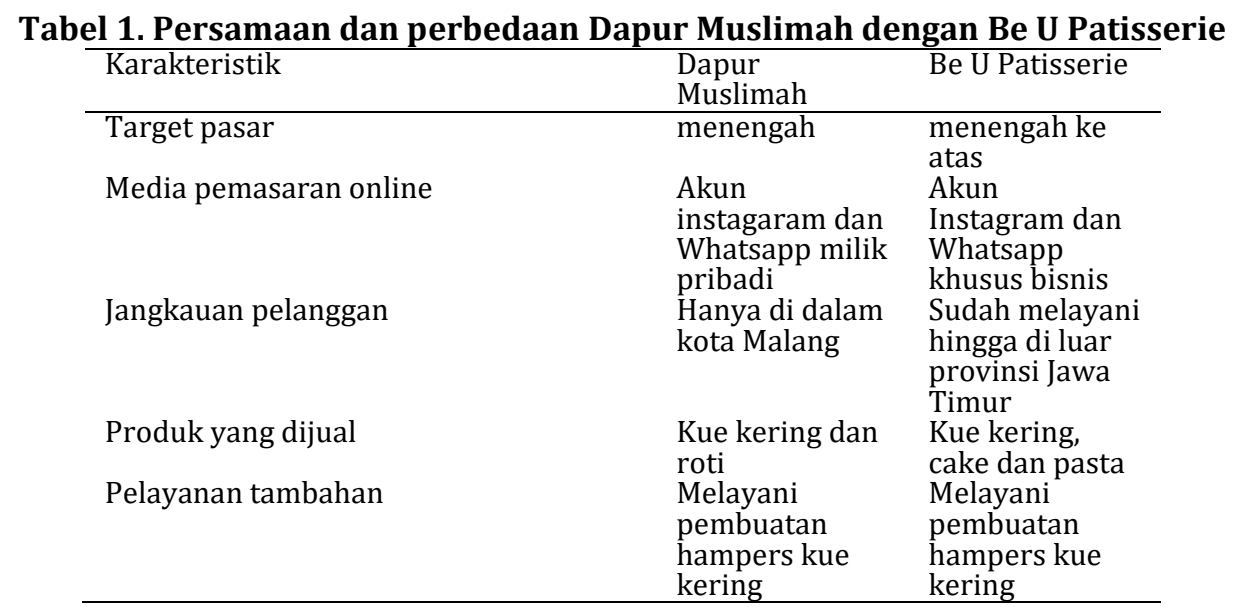

Tantangan Be U Patisserie dan Dapur Muslimah selama masa pandemi covid-19 yang melanda sejak 2020 adalah penurunan omzet yang drastic serta keterbatasan dalam melakukan promosi. Hal ini karena melemahnya daya beli masyarakat akibat pandemi Covid-19. Pelemahan ini menyebabkan masyarakat dan pengusaha lebih banyak menganggarkan uangnya untuk memenuhi hal lain daripada membeli kue Lebaran. Di samping itu, cara pemasaran yang biasanya dilakukan secara tatap muka dengan memberi sampel atau mengunjungi komunitas dan kelompok kegiatan juga jauh berkurang. Namun, setelah era new normal sampai sekarang, kedua usaha kue kering ini perlahan bangkit. Omzet yang dicapai justru lebih tinggi daripada sebelum pandemi. 


\section{Penerapan Komunikasi Pemasaran Terpadu}

Berdasarkan hasil wawancara dan pengamatan, peneliti melihat Be U Patisserie dan Dapur Muslimah menerapkan beberapa strategi komunikasi pemasaran terpadu untuk bertahan di masa pandemi. Di waktu lebaran tahun 2020 Be U Patisserie mendapat omzet sebesar 20.000.000 rupiah. Pada tahun 2021 omzet tersebut meningkat dua kali lipat menjadi 40.000.000 rupiah dan sudah memiliki seorang karyawan. Sementara itu Dapur Muslimah, sebelum pandemi setiap bulannya bisa mendapat omzet sekitar 7.000.000 rupiah. Namun ketika awal pandemi, pendapatannya merosot hingga 4.000.000 rupiah. Setelah masuk era new normal, sekitar bulan September 2020 sampai sekarang pendapatannya justru mulai kembali stabil bahkan meningkat. Pada Lebaran 2021, dia bisa mendapat omzet di atas 10.000 .000 rupiah per bulan. Di tahun ini Dapur Muslimah juga memiliki pegawai sebanyak dua orang.

Direct marketing. Be U Patisserie menerapkan beberapa elemen komunikasi pemasaran terpadu, strategi yang pertama adalah direct marketing. Fatma mengirim foto menu dan daftar harga pada calon pelanggan yang potensial melalui aplikasi Whatsapp. Be U Patisserie memilah mana pelanggan yang loyal mana yang baru dan mana yang belum pernah tahu produknya. Kemudian menggunakan status Whatsapp (WA) untuk mempromosikan dagangannya. Dia melakukan foto produk secara mandiri lalu mendesain flyer agar tampak menarik dan layak dipos di status WA. Secara rutin, Fatma mengunggah status dagangannya tiga kali dalam seminggu dan dalam satu kali update dia mengepos minimal tiga informasi.

Fatma merespon calon konsumen melalui percakapan di Whatsapp. Di awal jualan, Fatma menyukai cara ini karena efektif dalam mengenalkan produk. Ia dapat menjelaskan dengan detail apa yang ingin diketahui oleh konsumen. Meski harus melayani satu per satu para calon konsumennya, Fatma merasa dapat menyampaikan pesannya lebih jelas dan yakin jika calon konsumennya itu mampu menerima pesannya dengan baik. Untuk pelanggan tetap, Fatma juga kerap membagikan informasi terbaru seperti produk baru dan harganya melalui pesan langsung pada Whatsapp secara personal.

Sementara itu, direct marketing yang diterapkan Dapur Muslimah, yakni mengirimkan pesan melalui Whatsapp, baik secara personal ataupun ke grup chat. Selain itu, dia juga aktif membagikan status Whatsapp untuk memberi kabar pre-order untuk menu baru, atau pemberitahuan tentang diskon khusus. Selain itu, status yang dibagikan berupa testimoni dari para pelanggan, proses pembuatan, hasil jadi kuenya, sampai bahan baku yang digunakan. Sejauh ini respon yang diberikan oleh pelanggannya cukup baik. Setiap dia meng-update status selalu ada tanggapan yang masuk, baik untuk bertanya harga hingga bertanya kapan kue tersebut bisa dipesan. Ima melakukan update ini setiap dua hari sekali. Ima juga selalu menyimpan seluruh nomor kontak pelanggannya. Direct marketing ini bisa menjadi sarana promosi sekaligus transaksi pembelian seperti yang disampaikan oleh Ima sebagai berikut:

"Apalagi kebanyakan yang jadi pelanggan sudah saling menyimpan nomor kontak, jadi pemasaran lewat status Whatsapp paling sering digunakan. Ketika saya update status kue terbaru, cara mendapat respon juga mudah. Biasanya pelanggan yang ingin cari tahu informasi lebih banyak tinggal balas status kita setelah itu mereka juga bisa langsung melakukan transaksi" (Ima, Wawancara, 1 Juni 2021). 
Kehadiran fitur Whatsapp status memang menarik dan dapat dimanfaatkan untuk melakukan promosi berupa teks, gambar serta video. Pelaku usaha dapat melakukan update status atau mengubah foto profil untuk menarik konsumen. Namun, dibalik kelebihan Whatsapp terdapat beberapa kekurangan, yaitu keterbatasan jumlah penerima pada fitur broadcast sehingga jika ingin melakukan kegiatan pemasaran yang besar Whatsapp status bukan pilihan yang tepat. Selain itu, butuh perhatian tinggi dari pelaku usaha untuk sering melakukan update status dan mengirim chat secara personal untuk memastikan target yang disasar benar-benar terpapar promosi karena tidak semua orang akan melihat status yang ditayangkan (Andamisari, 2021).

Internet marketing. Fatma menggunakan media sosial Instagram sebagai sarana promosi produknya. Meski jumlah followernya masih sangat sedikit, hanya sekitar 140 sampai bulan Juni 2021, Fatma cukup aktif mengunggah postingan instastory. Pemasaran melalui Instagram menurut Fatma adalah yang paling efisien di masa pandemi karena media ini tengah digandrungi oleh masyarakat, tidak ada biaya untuk produksi serta dapat menjangkau pelanggan secara luas. Fatma membagikan postingan berupa berbagai gambar mulai dari gambar produk, jumlah orderan yang masuk, proses pembuatan, pengiriman produk dan testimoni dari customernya. Beragam gambar yang dipos tersebut tentu memberi interpretasi bahwa usahanya ini terpercaya dan memiliki kualitas yang bagus. Tidak lupa fitur instastory juga dimanfaatkan untuk memasarkan produk. Be U Patisserie tidak pernah lupa untuk mengirim ulang (repost) gambar atau video para pelanggannya yang menandai akunnya di Instagram. Di Instagram, eksistensi Be U Patisserie bisa menjadi lebih luas seperti yang disampaikan Fatma sebagai berikut:

\begin{abstract}
"Selain untuk marketing akun Instagram Be U Patisserie berfungsi sebagai galeri portofolio. Jadi melalui akun tersebut diharapkan dapat menjawab segala pertanyaan konsumen perihal produk. Serta diharapakan target bisnis untuk menjangkau konsumen di dalam dan luar kota dapat tercapai. Dari Instagram ini juga banyak orang yang tahu eksistensi bisnins kami di luar circle kami," (Fatma, Wawancara 2 Juni 2021).
\end{abstract}

Dapur Muslimah juga menerapkan internet marketing melalui media sosial Instagram. Namun, bedanya tidak ada akun khusus Dapur Muslimah, melainkan menggunakan akun pribadi Ima yang merangkap untuk mempromosikan seluruh produk jualannya. Akun ini memiliki 750 follower. Di akun tersebut Ima juga kerap membagikan konten mengenai gambar produk dagangannya, proses pembuatan, serta Dapur Muslimah juga pernah mendapat endorse dari influencer lokal di Malang. Selain membagikan konten di feed Instagram, Dapur Muslimah juga memanfaatkan menu instastory untuk promosi. Tidak lupa Dapur Muslimah mencantumkan nomor kontak agar calon konsumen bisa mencari info lebih lanjut atau bertansaksi melalui Whatsapp. Penggunaan Instagram sendiri diawali dari kesukaan Ima membagikan resepnya kepada para follower-nya. Tak disangka banyak followernya yang tertarik untuk mencicipi kue buatannya.

"Awalnya pakai IG untuk berbagi resep saja belum ada niatan untuk bisnis. Tapi makin ke sini makin banyak pelanggan yang berminat sama produk Dapur Muslimah, akhirnya sekalian saja saya pakai untuk berjualan. Yang awalnya dari akun pribadi aku ubah jadi akun bisnis," (Ima, Wawancara, 1 Juni 2021). 
Instagram yang tengah digandrungi masyarakat nyatanya mampu mendongkrak penjualan kedua merek ini. Komunikasi melalui foto dan caption dengan kreatif merupakan salah satu faktor penting dalam menarik perhatian konsumen. Aplikasi ini memiliki kekuatan dalam berbagi gambar yang terbukti punya hubungan kuat dalam mempengaruhi minat beli konsumen (Indika \& Jovita, 2017). Sayangnya, Dapur Muslimah kurang variatif dalam membuat konten di Instagram. Sebagian besar konten menampilkan foto produk saja serta foto proses pembuatan. Selain itu juga tidak konsisten memproduksi konten. Jeda postingan bisa lebih dari dua bulan. Berbeda dengan Be U Patisserie yang setiap bulan minimal mengunggah satu konten dan lebih variatif karena juga mengepos pemberitahuan open order yang informatif dengan grafis menarik. Adanya akun khusus penjualan yang tidak bercampur dengan akun pribadi akan lebih baik karena lebih fokus pada produk serta memudahkan konsumen dalam mengenal produk tersebut.

Sales promotion. Be U Patisserie memberikan promo berupa potongan harga 10 persen untuk pelanggan yang melakukan pembelian berulang. Meski promo ini tidak selalu ada pakemnya, jumlah potongan harga sering berganti menyesuaikan kondisi. Selain itu, bentuk sales promotion yang dilakukan adalah dengan memberi bonus produk. Bagi Fatma, pemberian bonus produk jauh lebih efektif serta lebih mengena pada pelanggan dan memicu pembelian kembali dibanding potongan harga. Oleh sebab itu, pemberian bonus produk lebih sering diterapkan.

"Seringnya ngasih bonus produk untuk jenis kue yang berbeda. Apalagi kalau ada baru biasanya bisa dijadikan bonus untuk awal-awal dan jadi promo juga. Ngasih bonus produk gini efektif buat pelanggan balik lagi beli kue di Be U Patisserie," (Fatma, Wawancara 2 Juni 2021).

Senada dengan Dapur Muslimah yang menggunakan sales promotion berupa memberi potongan harga bagi pelanggan yang membeli lima toples kue kering, memberi reward gratis ongkos kirim serta bonus satu toples bagi pelanggan yang membeli dua paket hampers. Potongan harga, gratis ongkos kirim, dan bonus ini membuat pelanggannya senang dan terdorong untuk membeli produk Dapur Muslimah lebih banyak lagi.

Bentuk sales promotion berupa pemberian sampel atau bonus suatu produk lebih efektif dalam mendorong pelanggan untuk melakukan keputusan pembelian. Adanya bonus tambahan ini menarik pelanggan dan juga sebagai ajang mengenalkan produk. Jika kualitas kue yang menjadi bonus ini ternyata memuaskan maka besar kemungkinan pelanggan untuk melakukan pembelian yang kedua kalinya. Secara perlahan konsumen lainnya juga akan ikut membeli produk tersebut (Setiani \& Nuzulia, 2014).

Advertising. Advertising merupakan hal baru yang dilakukan oleh Be U Patisserie. Ia tidak memasang iklan di media cetak atau media massa melainkan menggunakan jasa iklan paid promote di akun Instagram khusus kuliner di Tulugagung. Hal ini dilakukan agar nama Be U Patisserie makin dikenal oleh masyarakat Tulungagung. Memasang iklan di akun Instagram lokal dianggap lebih cepat, efisien, praktis, dan terjangkau. Tarif yang ditawarkan jasa promo bayaran ini berada di kisaran 75.000 rupiah untuk sekali tayang. Hasilnya, ada kenaikan pada jumlah konsumen setelah memasang iklan, tetapi tidak terlalu banyak. 


\begin{abstract}
"Pasang iklan berdampak pada kuantitas konsumen namun tidak begitu signifikan dibanding dengan direct marketing. Mungkin karena pangsa pasar di sini sedikit rendah dengan harga yang dipasang. Berbeda dengan konsumen-konsumen di kota besar yang sudah mulai menjangkau harga yang ditetapkan," (Fatma, Wawancara, 2 Juni 2021).
\end{abstract}

Sedangkan Dapur Muslimah tidak menerapkan advertising karena adanya keterbatasan tenaga. Tanpa advertising saja permintaan dari konsumen sudah sesuai dengan ekspektasi Ima. Ternyata penggunaan advertising efeknya tidak terlalu signifikan sehingga Fatma menjadikan advertising sebagai elemen komunikasi pemasaran terpadu yang terakhir. Sementara Ima sama sekali tidak menggunakan iklan karena dia merasa dengan elemen direct marketing, internet marketing dan sales promotion sudah cukup mendongkrak penjualannya.

Berdasar hasil wawancara dan observasi, Be U Patisserie dan Dapur Muslimah melakukan berbagai usaha agar dapat bertahan di masa pandemi dengan menggunakan komunikasi pemasaran terpadu, mengintegrasikan beberapa elemen untuk meningkatkan brand awareness dan penjualan. Seperti yang dilakukan penelitian sebelumnya, "Strategi Komunikasi Pemasaran Terpadu J\&C Cookies Bandung Dalam Meningkatkan Penjualan", memadukan enam elemen yakni periklanan, penjualan personal, promosi penjualan, penjualan langsung, acara \& sponsor, dan public relations. Karena usaha tersebut sudah cukup besar dan punya nama, maka elemen public relations dapat diaplikasikan. Selain itu, karena pemasaran ini dilakukan sebelum pandemi maka elemen acara dan sponsor serta penjualan personal juga bisa diterapkan. Berbeda dengan masa pandemi yang membuat cara memasarkan kue oleh Be U Patisserie dan Dapur Muslimah terbatas. Namun, keduanya mempunyai cara, yaitu dengan memaksimalkan fitur Whatsapp dan menggunakan Instagram untuk sarana pemasaran.

Lain pula dengan penelitian sebelumnya yang berjudul "Peran IMC Dalam Pemilihan Mommilk Manahan Solo Sebagai Pilihan Kunjungan Konsumen". Mommilk menggunakan tiga elemen antara lain advertising, public relation dan direct sale and promotion. Ternyata integrasi elemen komunikasi pemasaran terpadu yang dijalankan Mommilk termasuk dalam kategori positif. Secara garis besar kegiatan IMC Mommilk memiliki peran dalam menarik minat konsumen untuk berbelanja di Mommilk Manahan sebagai pilihan kunjungan.

Antara Be U Patisserie dan Dapur Muslimah terdapat persamaan dalam penggunaan elemen komunikasi pemasaran terpadu. Keduanya sama-sama menggunakan direct marketing, online marketing dan sales promotion. Namun, keduanya sepakat jika elemen yang paling berdampak adalah direct marketing. Keduanya adalah pemain baru dalam industri kue kering rumahan dan mereka juga ibu rumah tangga. Kesibukan mereka membagi waktu antara mengasuh anak dan menjalankan usahanya yang membuat Whatsapp dijadikan saluran utama untuk promosi. Karena selain langsung mengenai sasaran, juga bisa mendapat feedback secara langsung, bisa interaktif serta menjadi kelanjutan dari proses transaksi penjualan. Meski aplikasi Whatsapp digunakan untuk sarana pemasaran, tapi akun Whatsapp yang digunakan masih personal bukan akun bisnis.

Aplikasi Whatsapp tidak bisa dianggap enteng untuk digunakan sebagai media pemasaran. Berdasar data dari We are Social, rata-rata masyarakat Indonesia menggunakan Whatsapp selama 30,8 jam per bulan. Bahkan aplikasi tersebut menjadi yang paling popular di kalangan masyarakat. Tidak heran jika Indonesia bisa menduduki peringkat ketiga dunia dalam penggunaan Whatsapp (Conney Stephanie, 2021). Oleh 
sebab itu, tidak sedikit pebisnis yang menjadikan Whatsapp untuk memasarkan produk dan jasa karena memotong biaya marketing, lebih cepat, dan tepat mengenai target sasaran, serta konsumen dapat memberikan feedback sehingga akan terjalin interaksi dua arah secara langsung (Priantoro, 2019).

Yang kedua, fokus pemasaran melalui internet atau media online karena media ini yang paling banyak digunakan saat ini. Apalagi di masa pandemi yang mengharuskan kegiatan masyarakat secara offline berkurang sehingga banyak yang beralih ke dunia maya terutama ke media sosial. Instagram memiliki kekuatan visual sehingga gambar yang menaik dan punya kualitas bagus akan mendapat interaksi berupa komentar, like atau bertambahnya jumlah follower. Jumlah pengguna media sosial sendiri makin meningkat tiap tahunnya. Di Indonesia, dalam satu bulan diketahui sebanyak 53 juta orang aktif menggunakan Instagram (Suryanto et al., 2019). Bahkan Indonesia menempati posisi ketiga di dunia sebagai negara dengan jumlah pengguna Instagram tertinggi setelah Amerika dan Brazil (Krisna et al., 2019). Artinya masyarakat senang mengakses jejaring social dan Instagram mampu merebut hati netizen Indonesia.

Pengguna tidak hanya sekedar mencari hiburan tapi juga mengakses berita, informasi bahkan mengenai kuliner sesuai selera. Inilah yang membuat kedua usaha kue kering tersebut menjatuhkan pilihan media pemasaran pada Instagram. Karena tidak perlu biaya, dapat dijalankan sendiri dengan mudah, dan dengan cepat bisa menjangkau masyarakat luas. Pesan yang disampaikan oleh pelaku usaha lebih mudah diterima karena Instagram memiliki format sederhana, yakni foto dan capton sehingga efektif bagi pemasaran (Pasaribu, 2020). Foto produk yang ada di Instagram pun berhasil menarik minat konsumen untuk mencari informasi mengenai aneka kue kering lebih lanjut. Dari Instagram pula, keduanya mendapat pelanggan dari luar kota, sehingga produk mereka bisa dikenal lebih luas lagi.

Selain itu, Instagram dipilih karena saat ini keduanya kesulitan untuk melakukan pemasaran melalui tatap muka. Untuk meningkatkan kepercayaan konsumen, keduanya mengepos konten mulai dari pembuatan, foto produk, pengemasan, pengiriman, sampai testimoni dari pelanggan. Konten tersebut sudah dapat mewakili pertanyaan yang biasanya diajukan konsumen. Jika ada konsumen yang masih ingin tahu lebih lanjut biasanya menanyakan melalui kolom komentar atau direct message. Namun, baik Be U Patisserie dan Dapur Muslimah harus meningkatkan aktivitas di Instagram karena dampak yang dihasilkan besar. Dengan follower yang kurang dari seribu saja mereka sudah mendapat pendapatan lebih baik dibanding masa pandemi, apalagi jika mereka lebih aktif promosi di sana. Setidaknya punya jadwal tetap berapa kali dalam seminggu memosting konten, berapa kali dalam sehari memasarkan melalui instastory.

Di sisi lain, yang tidak kalah menarik adalah strategi sales promotion yang masih menjadi andalan para pelaku usaha untuk meningkatkan hasil penjualan. Baik potongan harga, bonus produk, hal ini memiliki tempat di hati konsumen. Uniknya baik pada Be U Patisserie dan Dapur Muslimah memiliki pandangan bahwa sales promotion berupa bonus produk lebih menarik konsumennya daripada potongan harga. Bagi mereka, bonus produk mampu mengikat konsumen secara psikologis dan mendorong untuk melakukan pembelian kembali (repurchase) sehingga tak sedikit keduanya memberikan bonus produk untuk pembelian kue kering dalam jumlah tertentu. Tentu saja yang mendapat bonus adalah konsumen mereka yang loyal. Strategi ini mampu membuat konsumen menjadi loyal dan tidak berpaling pada produk lain.

Dilihat dari penggunaan komunikasi pemasaran terpadu, Be U Patisserie mampu membaurkan keempat elemen yaitu online marketing, sales promotion, direct marketing dan advertising. Omzet yang dihasilkan pun dua kali lebih besar dibandingkan tahun 
2020. Sementara itu, Dapur Muslimah memadukan tiga elemen komunikasi terpadu, di antaranya online marketing, sales promotion dan direct marketing. Hasilnya omzet di tahun 2021 juga meningkat dibandingkan ketika masa pandemi. Peningkatan jumlah omzet Dapur Muslimah masih bisa dimaksimalkan dengan menambahkan elemen komunikasi pemasaran terpadu. Dapur Muslimah dapat menerapkan advertising, agar produknya bisa dikenal lebih luas lagi hingga ke luar provinsi. Tentu saja adanya tambahan cara pemasaran ini juga perlu diimbangi dengan jumlah tenaga yang ada agar bisa memenuhi permintaan konsumen dengan baik.

\section{Kesimpulan}

Strategi Be U Patisserie untuk bertahan di masa pandemi adalah menggunakan pendekatan komunikasi pemasaran terpadu. Strategi ini terbukti efektif meningkatkan penjualan bisnis kue di masa pandemi. Dari delapan elemen yang ada, Be U Patisserie menerapkan empat elemen yaitu advertising, online marketing, sales promotion, direct marketing. Kombinasi dari elemen tersebut membuat Be U Patisserie mampu eksis hingga sekarang, bahkan bisa memiliki pegawai baru dan omzetnya meningkat dua kali lipat. Di sisi lain, Dapur Muslimah menggunakan tiga elemen komunikasi pemasaran terpadu, antara lain direct marketing, online marketing dan sales promotion. Hasilnya, meski sempat jatuh di awal pandemi, Dapur Muslimah mampu bangkit bahkan bisa meraup omzet lebih besar dibanding sebelum masa pandemi. Selain itu Dapur Muslimah juga berhasil menambah dua orang pegawai setelah sebelumnya hanya dikelola oleh satu orang saja.

Baik Be U Patisserie dan Dapur Muslimah agar lebih peka dalam membaca peluang dalam situasi seperti ini karena tanpa diduga daya beli masyarakat yang sempat turun justru malah tinggi. Keduanya sukses memanfaatkan direct marketing melalui Whatsapp. Namun, agar terus berkembang perlu lebih banyak memaksimalkan fitur-fitur di Instagram untuk pemasaran secara online supaya produk mereka makin dikenal dan meningkatkan penjualan hingga ke luar Jawa. Bagi yang memiliki usaha sejenis dapat menerapkan strategi komunikasi pemasaran terpadu agar dapat bertahan di masa pandemi.

\section{Referensi}

Aulia Putri Pandamsari. (2020). Lebaran di tengah pandemi jatuh bangun bisnis kue kering. Diakses dari Lokadata : https://lokadata.id/artikel/lebaran-di-tengahpandemi-jatuh-bangun-bisnis-kue-kering

Andamisari, D. (2021). Penggunaan Status Whatsapp Sebagai Digital Marketing Warga Kecamatan Medan Satria Bekasi Di Era New Normal. Jurnal Lugas, 5(1), 66-72.

Bahtiar, R. A., \& Saragih, J. P. (2020). Dampak Covid-19 Terhadap Perlambatan. Kajian Singkat Terhadap Isu Aktual Dan Strategis, 12, 20.

Hardilawati, W. laura. (2020). Strategi Bertahan UMKM di Tengah Pandemi Covid-19. Jurnal Akuntansi Dan Ekonomika, 10(1), 89-98. https://doi.org/10.37859/jae.v10i1.1934

Indika, D. R., \& Jovita, C. (2017). Media Sosial Instagram Sebagai Sarana Promosi Untuk Meningkatkan Minat Beli Konsumen. Jurnal Bisnis Terapan, 1(01), 25-32. https://doi.org/10.24123/jbt.v1i01.296

Isnaini, S. (2004). Implementasi Komunikasi Pemasaran Terpadu sebagai Penyampai Pesan Promosi Usaha Kecil Menengah (UKM) di Indonesia. Jurnal Masyarakat Kebudayaan Dan Politik, 22(4), 324-332.

Krisna, D. F., Handayani, P. W., \& Azzahro, F. (2019). The antecedents of hashtag and 
geotag use in smart tourism: case study in Indonesia. Asia Pacific Journal of Tourism Research, 24(12), 1141-1154. https://doi.org/10.1080/10941665.2019.1665559

Miles, Matthew B, \& Huberman, Michael A. (2014). Qualitative Data Analysis A Method Sourcebook Third Edition. United States of America : Sage Publication.

Pasaribu, R. (2020). Optimalisasi Media Online Sebagai Solusi Promosi Pemasaran Umkm Di Semarang Pada Masa Pandemi Covid-19. Jurnal Komunikasi Dan Media, 1(1), 33. https://doi.org/10.24167/jkm.v1i1.2848

Priantoro, B. (2019). Strategi Komunikasi Pemasaran Melalui Media Whatsapp (Studi Kasus Garuda Indonesia Solo). Prosiding Seminar Nasional Cendekiawan, 2. https://doi.org/10.25105/semnas.v0i0.5783

Setiani, N. D., \& Nuzulia, S. (2014). Efektivitas Personal Selling dan Sales Promotion Dengan Sampel Produk Terhadap Keputusan Pembelian Konsumen. Journal of Social and Industrial Psychology, 3(1), 41-47.

Suryanto, T. L. M., Puteri, H. A., \& Pratama, A. (2019). Eksplorasi Teori Gratifikasi untuk Layanan Jejaring Sosial: Studi Kasus Sikap Pengguna terhadap Instagram di Indonesia. Indonesian Journal of Information Systems, 1(2), 108. https://doi.org/10.24002/ijis.v1i2.1922

Thaha, A. F. (2020). Dampak Covid-19 Terhadap UMKM di Indonesia. Jurnal Brand, 2(1), 147-153.

Vernia, D. M. (2017). Optimalisasi Media Sosial Sebagai Sarana Promosi Bisnis Online Bagi Ibu Rumah Tangga Untuk. UTILITY L Junral Ilmiah Pendidikan Dan Ekonomi, 1(2), 105-118. http://journal.stkipnurulhuda.ac.id/index.php/utility/article/view/71

Yamali, F. R., \& Putri, R. N. (2020). Dampak Covid-19 Terhadap Ekonomi Indonesia. Ekonomis: Journal of Economics and Business, 4(2), 384. https://doi.org/10.33087/ekonomis.v4i2.179 